\title{
Organizational Citizenship Behavior for the Environment (OCBE) on Generation $X$ and Generation Y Millennial
}

\author{
A. M. Nur Huda Kalimullah ${ }^{1}$, Lenny C Nawangsari ${ }^{2}$, Ahmad H Sutawijaya ${ }^{3}$ \\ \{nurhuda61@gmail.com ${ }^{1}$, lenny.christina@mercubuana.ac.id ${ }^{2}$, a.h.sutawijaya@mercubuana.ac.id ${ }^{3}$ \} \\ Universitas Mercu Buana, Jakarta, Indonesia ${ }^{123}$
}

\begin{abstract}
OCBE in financial organizations is needed to support Sustainability Financial. The purpose of this study was to determine the influence of leadership, organizational culture and job satisfaction on Organizational Citizenship Behavior for the Environment (OCBE) in generation Y millennia and generation X. This type of research used quantitative research and survey methods. The study population was employees of financial organizations in Jakarta with a sample of 60 people. The results of this study prove that Leadership and Organizational Culture have an effect on OCBE through Work Satisfaction, except for the $\mathrm{X}$ generation group who stated that leadership had no effect on OCBE.
\end{abstract}

Keywords: Leadership, Organizational Culture, Work Satisfaction, OCBE

\section{Introduction}

Organizational sustainability is one of the challenges that must be answered by all organizations in this globalization era. Likewise, organizations engaged in finance have emphasized financial sustainability as one of the important goals of the organization. Several regulations related to sustainable finance were made with the aim of assisting organizations in creating systems and carrying out implementation related to financial sustainability. To support the implementation of financial sustainability, it is necessary to support human resources who are aware of environmental conservation programs made by organizations / companies [1]. Employee voluntary behavior related to environmental awareness at work (OCBE) is something that must be cultivated in the organization.

Based on observations in the field, OCBE has not been maximally implemented on research objects related to efforts to save energy in the workplace, environmental cleanliness, and use of paper in the workplace. Some of the factors that influence OCBE based on previous research are Technology, Leadership, Organizational Culture, Job Satisfaction, Work Discipline \& Work Motivation. After the pre-survey was carried out, it was found that the 3 biggest variables were considered to influence OCBE, namely leadership, work culture and job satisfaction. The problem that still arises related to leadership is the lack of the role of the leader in motivating and supervising employees. For organizational culture it was found that the understanding and application of organizational culture by employees was not optimal. 
Employee job satisfaction is also not optimal related to the relationship between employees, employee work challenges, and employee job protection. Several previous studies related to OCBE stated the importance of corporate environmental policies to support employee environmental initiatives [2,3]. Leadership is important to increase employee job satisfaction [4,5]. Organizational culture is an important element that greatly affects employee job satisfaction [6,7]. Job satisfaction will increase employee OCBE behavior $[8,9]$. Good leadership will affect employee OCBE $[10,11,12,13]$. There is a positive effect related to organizational culture on OCBE in organizations [14].

Based on the above phenomena, research was carried out related to the influence of leadership and organizational culture on OCBE mediated job satisfaction in employees in 2 generations, namely generation Y millennia and generation $\mathrm{X}$. The theory that underlies this research are:

\subsection{Leadership}

Leadership is a life that affects the lives of others. Leadership is something that is inherent in a person who has certain traits such as personality, ability and capacity [15]. There are 3 dimensions of leadership, namely: 1) The relationship between leaders and subordinates; 2) Degree of task composition and 3) Position of power of a leader [16].

\subsection{Organizational Culture}

Organizational culture is a set of values and norms that have been in effect for a long time, adopted by members of the organization (employees) as a norm of behavior in solving company problems. A strong and positive culture is very influential on the behavior and effectiveness of company performance. The dimensions of organizational culture are: Trust, Aggressiveness, Personality \& Performance ([17]

\subsection{Work Satisfaction}

Job satisfaction is a general attitude towards one's job as the difference between the amount of reward received by workers and the amount of reward that is believed to be received. Job satisfaction is an important thing that individuals have at work. (Robbins, 2015). Factors that affect a person's job satisfaction are psychological factors, social factors, physical factors, financial factors [15].

\subsection{Organizational Citizenship Behavior for the Environment (OCBE)}

OCBE is individual, voluntary, and discretionary social behavior that is not explicitly recognized by formal management systems and which contributes to effective environmental management by organizations. three easily interpreted dimensions to measure OCBE, namely, environmental initiatives, environmental assistance and civil society engagement [18]. Based on previous theory and research, the research hypothesis is presented as follows:

H1a: Leadership affects Work Satisfaction in the Millennial Generation group H1b: Leadership has an effect on Work Satisfaction in the Generation X group H2a: Organizational Culture affects Work Satisfaction in the Millennial Generation group H2b: Organizational Culture affects Work Satisfaction in the Generation X group H3a: Leadership affects OCBE in the Millennial Generation group H3b: Leadership affects OCBE in the Generation X group H4a: Organizational Culture affects OCBE in the Millennial Generation group H4b: Organizational Culture affects OCBE in the Generation X group 
H5a: Work Satisfaction affects OCBE in the Millennial Generation group

H5b: Work Satisfaction has an effect on OCBE in Generation X group

H6a: Organizational Culture influences OCBE through Work Satisfaction in the Millennial Generation group

H6b: Organizational Culture influences OCBE through Work Satisfaction in Generation X group

H7a: Leadership affects OCBE through Work Satisfaction in the Millennial Generation group

H7b: Leadership affects OCBE through Work Satisfaction in Generation X group

\section{Research Method}

This type of research is a quantitative study using survey methods. The research object is several financial institutions in Jakarta with a sample of 60 people. Data analysis used SEM with the Generalized Structural Component Analysis (GSCA) program.

\section{Results and Discussion}

The statistical analysis in this study used Generalized Structural Component Analysis (GSCA). The stages of the GSCA analysis are as follows:

\subsection{Validity and Reliability Test}

\subsubsection{Discriminant validity}

Discriminant validity is a reflexive indicator measurement based on cross loading with its latent variables.

Table 1. Discriminant validity test results

\begin{tabular}{|c|c|}
\hline \multicolumn{2}{|c|}{ Group 1 (Generation Y Millennia) } \\
\hline Variable & Average variance extracted (AVE) \\
\hline Leadership (X1) & 0,655 \\
\hline Organizational Culture (X2) & 0,759 \\
\hline Work Satisfaction (Y1) & 0,776 \\
\hline OCBE (Y2) & 0,657 \\
\hline \multicolumn{2}{|c|}{ Group 2 (Generation X) } \\
\hline Variable & Average variance extracted (AVE) \\
\hline Leadership (X1) & 0,761 \\
\hline Organizational Culture (X2) & 0,755 \\
\hline Work Satisfaction (Y1) & 0,813 \\
\hline OCBE (Y2) & 0,788 \\
\hline
\end{tabular}

Source: Primary data processed (2020) 
The results of the discriminant validity test where all the Average variance extracted (AVE) values are greater than 0.50 so that it can be concluded that they meet the discrimens validity requirements.

\subsubsection{Composite Reliability}

Table 2. Composite Reliability Test Results

\begin{tabular}{ccc}
\hline & Group 1 (Generation Y Millennia) & \\
Variable & Composite Reliability & Description \\
Leadership (X1) & 0,894 & Reliable \\
Organizational Culture (X2) & 0,946 & Reliable \\
Work Satisfaction (Y1) & 0,941 & Reliable \\
OCBE (Y2) & 0,886 & Reliable \\
& Group 2 (Generation X) & \\
Variable & Composite Reliability & Description \\
Leadership (X1) & 0,936 & Reliable \\
Organizational Culture (X2) & 0,945 & Reliable \\
Work Satisfaction (Y1) & 0,952 & Reliable \\
OCBE (Y2) & 0,944 & Reliable \\
\hline
\end{tabular}

Source: Primary data processed (2020)

The results of the composite reliability test show a satisfactory value, where all latent variables are reliable because all variable values have a composite reliability value $\geq 0.60$.

\subsection{Structural Equation Modeling}

This study uses a structural equation model of the GSCA approach. Before analyzing, first the empirical research model is tested or evaluated. The results of testing the empirical model of this study can be seen in the image below:

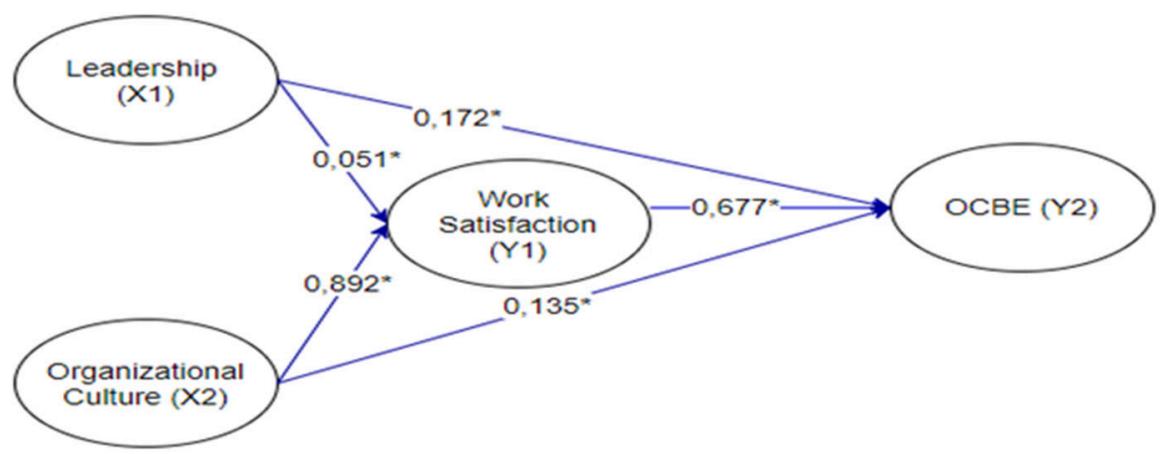

Fig 1. Results of Analysis with GSCA in Group 1 


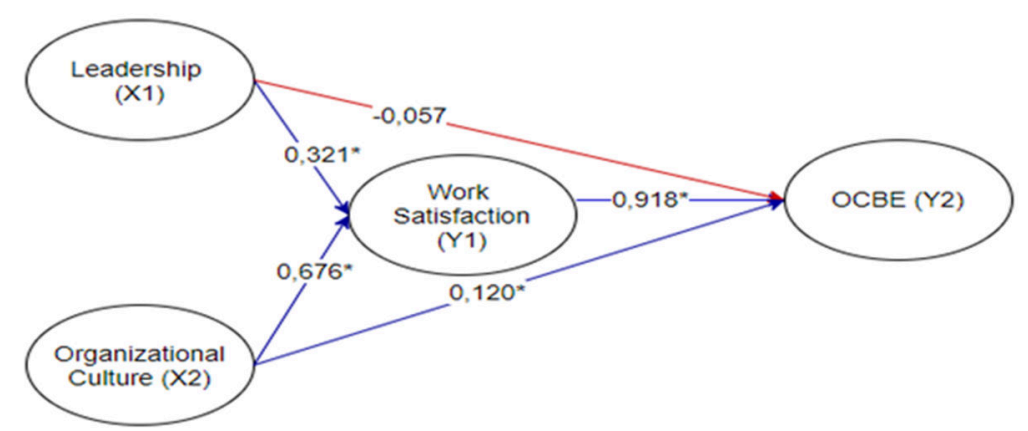

Picture Note:

Fig 2. Results of Analysis with GSCA in Group 2

*): Significant at the $5 \%$ alpha level

Blue Arrow: Significant at the 5\% alpha level in the structural model

Red Arrow: Not significant at 5\% alpha level in structural models

\subsection{Goodness of Fit Model}

The theoretical model in the research conceptual framework is said to be fit if it is supported by empirical data. There are two indications to see whether the model used is good, namely the goodness of fit of the structural model and the goodness of fit of the overall model. The results of testing the goodness of fit of the structural model and the overall model are in accordance with the results of the hypothetical GSCA Model analysis, namely the goodness of fit overall model supported by empirical data is presented in Table 3.

Table 3. Goodness of Fit Overall Model Test Results

\begin{tabular}{llll}
\hline Criteria & Cut-of value & Model results & Description \\
\hline SRMR & $\leq 0,08$ & 0,081 & Enough model \\
GFI & $\geq 0,90$ & 0,972 & Good model \\
\hline
\end{tabular}

Source: Primary data processed (2020)

The results of the Goodness of Fit Overall Model test based on Table 3 show that SRMR and GFI have met the cut off value, so the GSCA model in this study is suitable and suitable for use, so that it can be interpreted for further discussion.

\subsection{Variable Measurement Model}

The conversion of the path diagram into a measurement model for each of the Leadership (X1), Organizational Culture (X2), Work Satisfaction (Y1) and OCBE (Y2) variables can be seen in the table below.

Table 4. Variable Leadership (X1) Measurement Model

\begin{tabular}{cccc}
\hline \multicolumn{4}{c}{ Group 1 (Generation Y Millennia) } \\
\hline Indicator & Estimate & SE & CR \\
\hline X1.1 & 0.800 & 0.070 & $11.48^{*}$ \\
X1.2 & 0.848 & 0.024 & $35.71^{*}$ \\
X1.3 & 0.774 & 0.012 & $66.71^{*}$
\end{tabular}




\begin{tabular}{cccc} 
X1.4 & 0.889 & 0.015 & $59.03^{*}$ \\
X1.5 & 0.792 & 0.078 & $10.11^{*}$ \\
\hline X1.6 & \multicolumn{4}{c}{0.745} & 0.054 & $13.73^{*}$ \\
\hline \multicolumn{4}{c}{ Group 2 (Generation X) } \\
\hline X1.1 & 0.867 & 0.004 & $203.99^{*}$ \\
X1.2 & 0.840 & 0.021 & $40.3^{*}$ \\
X1.3 & 0.856 & 0.016 & $54.86^{*}$ \\
X1.4 & 0.864 & 0.022 & $39.07^{*}$ \\
X1.5 & 0.922 & 0.004 & $258.42^{*}$ \\
X1.6 & 0.882 & 0.001 & $948.91^{*}$ \\
\hline
\end{tabular}

$\mathrm{CR} *=$ significant at .05 level

Source: Primary data processed (2020)

The variable leadership measurement model also informs that Indicator X1.4 has the greatest loading factor value for group 1 and indicator X1.5 has the largest loading for group 2. This means that X1.4 and X1.5 are the most dominant indicators in measuring variables. Leadership.

Table 5. Organization Culture (X2) Variable Measurement Model

\begin{tabular}{cccc}
\hline \multicolumn{4}{c}{ Group 1 (Generation Y Millennia) } \\
\hline Indicator & Estimate & SE & CR \\
\hline X2.1 & 0.871 & 0.010 & $85.16^{*}$ \\
X2.2 & 0.803 & 0.009 & $92.58^{*}$ \\
X2.3 & 0.909 & 0.017 & $54.01^{*}$ \\
X2.4 & 0.871 & 0.047 & $18.66^{*}$ \\
X2.5 & 0.900 & 0.028 & $31.88^{*}$ \\
X2.6 & 0.833 & 0.035 & $23.96^{*}$ \\
X2.7 & 0.906 & 0.024 & $37.78^{*}$ \\
\hline & Group 2 (Generation X) & \\
\hline X2.1 & 0.857 & 0.015 & $56.14^{*}$ \\
X2.2 & 0.887 & 0.033 & $26.56^{*}$ \\
X2.3 & 0.887 & 0.008 & $108.79^{*}$ \\
X2.4 & 0.906 & 0.030 & $30.15^{*}$ \\
X2.5 & 0.859 & 0.049 & $17.36^{*}$
\end{tabular}




\begin{tabular}{cccc}
$\mathrm{X} 2.6$ & 0.776 & 0.054 & $14.35^{*}$ \\
$\mathrm{X} 2.7$ & 0.904 & 0.051 & $17.64^{*}$ \\
\hline
\end{tabular}

$\mathrm{CR} *=$ significant at .05 level

Source: Primary data processed (2020)

The measurement model for Organizational Culture Variables also informs that Indicator $\mathrm{X} 2.3$ has the greatest loading factor value for group 1 and indicator X2.4 has the largest loading for group 2. This means that X2.3 and X2.4 are the most dominant indicators in measuring Organizational Culture Variables.

Table 6. Work Satisfaction (Y1) Variable Measurement Model

\begin{tabular}{cccc}
\hline \multicolumn{4}{c}{ Group 1 (Generation Y Millennia) } \\
\hline Indicator & Estimate & SE & CR \\
\hline Y1.1 & 0.828 & 0.016 & $52.78^{*}$ \\
Y1.2 & 0.891 & 0.071 & $12.47^{*}$ \\
Y1.3 & 0.910 & 0.025 & $35.9^{*}$ \\
Y1.4 & 0.899 & 0.010 & $90.76^{*}$ \\
Y1.5 & 0.906 & 0.032 & $28.24^{*}$ \\
Y1.6 & 0.847 & 0.030 & $28.29^{*}$ \\
\hline \multicolumn{4}{c}{ Group 2 (Generation X) } \\
Y1.1 & 0.931 & 0.009 & $109.18^{*}$ \\
Y1.3 & 0.897 & 0.054 & $16.75^{*}$ \\
Y1.4 & 0.884 & 0.047 & $18.76^{*}$ \\
Y1.5 & 0.891 & 0.027 & $33.07^{*}$ \\
Y1.6 & 0.887 & 0.026 & $34.6^{*}$ \\
\hline
\end{tabular}

$\mathrm{CR} *=$ significant at .05 level

Source: Primary data processed (2020)

The Work Satisfaction variable measurement model also informs that the Y1.3 indicator has the largest loading factor value for group 1 and the Y1.1 indicator has the largest loading for group 2. This means that Y1.3 and Y1.1 are the most dominant indicators in measuring Work Satisfaction Variable.

Table 7. OCBE (Y2) Variable Measurement Model

\begin{tabular}{llll}
\hline \multicolumn{4}{c}{ Group 1 (Generation Y Millennia) } \\
\hline Indicator & Estimate & SE & CR \\
\hline
\end{tabular}




\begin{tabular}{cllc}
\hline Y2.1 & 0.783 & 0.079 & $9.97^{*}$ \\
Y2.2 & 0.901 & 0.019 & $48.25^{*}$ \\
Y2.3 & 0.679 & 0.081 & $8.34^{*}$ \\
Y2.4 & 0.757 & 0.044 & $17.16^{*}$ \\
Y2.5 & 0.903 & 0.022 & $41.27^{*}$ \\
Y2.6 & 0.818 & 0.031 & $26.14^{*}$ \\
\hline \multicolumn{4}{c}{ Group 2 (Generation X) } \\
\hline Y2.1 & 0.931 & 0.015 & $61.73^{*}$ \\
Y2.2 & 0.826 & 0.020 & $41.2^{*}$ \\
Y2.3 & 0.918 & 0.028 & $32.82^{*}$ \\
Y2.4 & 0.879 & 0.007 & $129.56^{*}$ \\
Y2.5 & 0.862 & 0.049 & $17.58^{*}$ \\
Y2.6 & 0.905 & 0.019 & $47.31^{*}$ \\
\hline
\end{tabular}

$\mathrm{CR} *=$ significant at .05 level

Source: Primary data processed (2020)

The OCBE variable measurement model also informs that the Y2.5 indicator has the largest loading factor value for group 1 and the Y2.1 indicator has the largest loading for group 2. This means that $\mathrm{Y} 2.5$ and $\mathrm{Y} 2.1$ are the most dominant indicators in measuring variables. OCBE.

\subsection{Hypothesis Testing Results (Structural Model Testing Results)}

In the structural model, several hypotheses on the relationship between variables (direct influence) are tested. The complete results of testing the relationship between the research variables are presented in the table below.

Table 8. Results of Research Hypothesis Testing (Direct Effect)

\begin{tabular}{llllll}
\hline Hypothesis & Direct Influence & $\begin{array}{l}\text { Path } \\
\text { Coefficient }\end{array}$ & $\begin{array}{l}\text { Standard } \\
\text { Error }\end{array}$ & $\begin{array}{l}\text { Critical } \\
\text { Ratio }\end{array}$ & Description \\
\hline Generation Y Millennia (Group 1) & & \\
\hline H1 & $\begin{array}{l}\text { Leadership -> Work } \\
\text { Satisfaction }\end{array}$ & 0.051 & 0.024 & $2.15^{*}$ & Significant \\
H2 & $\begin{array}{l}\text { Organizational } \\
\text { Culture -> Work } \\
\text { Satisfaction }\end{array}$ & 0.892 & 0.016 & $54.53^{*}$ & Significant \\
H3 & $\begin{array}{l}\text { Leadership -> OCBE } \\
\text { Organizational }\end{array}$ & 0.172 & 0.047 & $3.62^{*}$ & Significant \\
H4 & $\begin{array}{l}\text { Culture -> OCBE } \\
\text { Work Satisfaction -> } \\
\text { OCBE }\end{array}$ & 0.135 & 0.039 & $3.44^{*}$ & Significant \\
H5 & & 0.077 & $8.82^{*}$ & Significant \\
\hline
\end{tabular}




\begin{tabular}{|c|c|c|c|c|c|}
\hline \multicolumn{6}{|c|}{ Generation X (Group 2) } \\
\hline $\mathrm{H} 1$ & $\begin{array}{l}\text { Leadership }->\text { Work } \\
\text { Satisfaction }\end{array}$ & 0.321 & 0.089 & $3.6^{*}$ & Significant \\
\hline $\mathrm{H} 2$ & $\begin{array}{l}\text { Organizational } \\
\text { Culture -> } \\
\text { Satisfaction }\end{array}$ & 0.676 & 0.078 & $8.66^{*}$ & Significant \\
\hline $\mathrm{H} 3$ & Leadership -> OCBE & -0.057 & 0.049 & 1.17 & $\begin{array}{l}\text { No } \\
\text { Significant }\end{array}$ \\
\hline $\mathrm{H} 4$ & $\begin{array}{l}\text { Organizational } \\
\text { Culture -> OCBE }\end{array}$ & 0.120 & 0.020 & $6.1^{*}$ & Significant \\
\hline H5 & $\begin{array}{l}\text { Work Satisfaction -> } \\
\text { OCBE }\end{array}$ & 0.918 & 0.091 & $10.13^{*}$ & Significant \\
\hline
\end{tabular}

$\mathrm{CR} *=$ significant at .05 level

Source: Primary data processed (2020)

Apart from testing the direct effect, multivariate modeling is also known as the indirect effect. The indirect effect is the product of 2 (two) direct effects. The indirect effect is stated as significant if the two direct effects that form it are significant, if one or both of them are not significant then the indirect effect is not significant. The following shows the results of the indirect effect.

Table 9. Results of Research Hypothesis Testing (Indirect Effect)

\begin{tabular}{|c|c|c|c|c|}
\hline Hypothesis & Relationship & Coefficient & Description & Conclusion \\
\hline \multicolumn{5}{|c|}{ Generation Y Millennia (Group 1) } \\
\hline H6 & Leadership $->$ & & $\begin{array}{lll}\text { Leadership } & -> & \text { Work }\end{array}$ & \\
\hline \multirow[b]{2}{*}{$\mathrm{H} 7$} & $\begin{array}{l}\text { Work } \\
\text { Satisfaction -> } \\
\text { OCBE }\end{array}$ & 0.035 & $\begin{array}{l}\text { Satisfaction (Sig.), } \\
\text { Work Satisfaction -> } \\
\text { OCBE (Sig.) }\end{array}$ & Significant \\
\hline & $\begin{array}{l}\text { Organizational } \\
\text { Culture -> } \\
\text { Work } \\
\text { Satisfaction -> } \\
\text { OCBE }\end{array}$ & 0.604 & $\begin{array}{l}\text { Organizational Culture -> } \\
\text { Work Satisfaction (Sig.), } \\
\text { Work Satisfaction -> } \\
\text { OCBE (Sig.) }\end{array}$ & Significant \\
\hline \multicolumn{5}{|c|}{ Generation X (Group 2) } \\
\hline H6 & $\begin{array}{l}\text { Leadership }-> \\
\text { Work } \\
\text { Satisfaction }-> \\
\text { OCBE }\end{array}$ & 0,295 & $\begin{array}{l}\text { Leadership }->\text { Work } \\
\text { Satisfaction (Sig.), } \\
\text { Work Satisfaction } \\
\text { OCBE (Sig.) }\end{array}$ & Significant \\
\hline $\mathrm{H} 7$ & $\begin{array}{l}\text { Organizational } \\
\text { Culture -> } \\
\text { Work } \\
\text { Satisfaction }-> \\
\text { OCBE }\end{array}$ & 0,621 & $\begin{array}{l}\text { Organizational Culture -> } \\
\text { Work Satisfaction (Sig.), } \\
\text { Work Satisfaction -> } \\
\text { OCBE (Sig.) }\end{array}$ & Significant \\
\hline
\end{tabular}

Source: Primary data processed (2020)

The results of the analysis show that all relationships between variables on the direct effect show significant results, but there is one direct effect that is not significant, namely the 
relationship between Leadership and OCBE in the Generation X Group. Based on Table 9, the results of the indirect effect test of the structural model are described and significant results are obtained in Group 1 and Group 2. To provide a clear description of the model of the relationship between the latent variables of each path in this study, it is seen as visualization in Figure 1. for Group 1 (Generation Y Millennia) and Figure 2 for Group 2 (Generation X).

\subsection{Discussion \\ 3.6.1 Leadership affects Work Satisfaction}

This study proves that leadership has an effect on work satisfaction in both groups. This indicates that the better the leadership in the organization, the employee job satisfaction will increase for employees from generation Y millennia and generation X. In leadership, the most dominant thing according to generation Y millennia employees is related to the task structure, namely leaders have encouraged their subordinates to be able to realize work plans. Whereas for X generation employees, the dominant thing related to Position power is that the leader already has the ability to command subordinates. This is what causes leadership to affect employee work satisfaction.

\subsubsection{Organizational Culture affects Work Satisfaction}

Organizational Culture affects Work Satisfaction in both groups. This means that the better the Organizational Culture will increase Work Satisfaction in the Y Millennia and Generation X generation groups. Y Millennia employees feel that related to Organizational Culture the dominant thing is the members' aggressiveness to complete their work and not always depend on the leadership. Meanwhile, according to generation Y employees, Millennia is the activeness of members in setting work plans and trying to complete it well. This Organizational Culture condition causes increased Work Satisfaction among employees.

\subsubsection{Leadership has an effect on OCBE}

This study proves that there are differences in results between group 1 and group 2. For the Y millennia generation group, leadership has an effect on OCBE. Meanwhile, the Y generation group stated that leadership had no effect on OCBE. The group of X generation employees stated that what had to be improved in leadership was Leader member relations, namely communication between leaders and employees so that OCBE. This is a possibility that causes Leadership to have no effect on OCBE. Meanwhile, according to generation Y employees, what needs to be improved is related to Position power, namely the assertiveness of leaders in making decisions.

\subsubsection{Organizational Culture affects OCBE}

The results of this study were Organizational Culture had an effect on OCBE in both groups. This means that the better the Organizational Culture, the better OCBE employees will be in both groups. The thing that needs to be improved regarding Organizational Culture according to the Y Millennia generation employee group is so that employees make more efforts to develop themselves and their abilities. Meanwhile, according to the $\mathrm{X}$ generation workers group, it is so that employees can manage differences by respecting differences of opinion in order to find the best thing in completing work so that OCBE can increase. 


\subsubsection{Work Satisfaction has an effect on OCBE}

This study proves that Work Satisfaction has an effect on OCBE. This states that the better the Work Satisfaction in the organization, the better the OCBE for the company for employees from generation $\mathrm{Y}$ millennia and generation $\mathrm{X}$. The dominant thing related to Work Satisfaction according to generation $\mathrm{Y}$ employees is that employees can overcome work challenges in completing tasks. Meanwhile, according to generation X employees the most influential is the existence of a harmonious working relationship in interacting with superiors.

\subsubsection{Leadership affects OCBE through Work Satisfaction}

The results of this study prove that Leadership has an effect on OCBE through Work Satisfaction. This means that the influence of Leadership on OCBE through Work Satisfaction is greater than the coefficient of direct influence between Leadership on OCBE for employees from generation $\mathrm{Y}$ millennia and generation $\mathrm{X}$ on the research object under study. Associated with OCBE, the most dominant thing according to the $\mathrm{X}$ generation employee group is the existence of Eco Initiatives - among employees with their behavior in disposing of garbage in their place. Meanwhile, the most dominant group for the Generation Y Millennials is Eco Helping - that is, employees spontaneously give their time to help colleagues to be aware of the environment in every job.

\subsubsection{Organizational Culture influences OCBE through Work Satisfaction}

This study proves that Organizational Culture has an effect on OCBE through Work Satisfaction, which means that Work Satisfaction plays a role in strengthening the relationship between Organizational Culture and OCBE. This suggests that the influence of Organizational Culture on OCBE through Work Satisfaction is greater than the coefficient of direct influence between Organizational Culture on OCBE in the two groups studied. According to the group $\mathrm{X}$ generation employees are Eco Initiatives, namely habits to save energy, for example by turning off electricity when not needed. Meanwhile, according to generation Y millennia, it is Eco Civic Engagement, which is so that employees can update information about the environment carried out by the organization so that they can participate in these activities.

\section{Conclusions}

This study proves that Leadership and Organizational Culture have an effect on OCBE through Work Satisfaction, except for the X generation group who stated that leadership had no effect on OCBE. While the variable that most influences work satisfaction is organization culture so to improve work satisfaction an organization must focus on the implementation of organizational culture.

Suggestions for organizations regarding research results are: (1) Organizations can conduct Leadership and communication training to improve good communication between superiors and subordinates; (2) Organizations can carry out capacity building for selfdevelopment and employee capabilities; (3) The organization can improve the monitoring system related to the achievement of employee duties; (4) Organizations can improve information systems and update information about the environment; (5) For future 
researchers, it is hoped that they can explore other variables related to OCBE and expand the object of research and increase the number of samples.

\section{References}

[1] Nawangsari, L. C., \& Sutawidjaya, A. H. (2019, May). How the Green Human Resources Management (GHRM) Process Can Be Adopted for the Organization Business?. In1st International Conference on Economics, Business, Entrepreneurship, and Finance (ICEBEF 2018). Atlantis Press.

[2] Chithra, M., \& J yothi, P. (2017). Eco-civic Engagement-A dimension of OCBE. International Journal of Human Resource Development and Management. Volume 7, Number 1 (2017), pp. $1-12$

[3] Haripatworo L. \& Bernadeta I. (2017). Organization citizenship behavior for the environment (OCB-E) karyawan perusahaan perbankan di Semarang. Forum manajemen Indonesia (FMI).

[4] Belias, D., \& Koustelios, A. (2014). Organizational culture and job satisfaction: A review. International Review of Management and Marketing, 4(2), 132-149.

[5] Atmojo, M. (2015). The influence of transformational leadership on job satisfaction, organizational commitment, and employee performance. International research journal of business studies, 5(2)

[6] Belias, D., \& Koustelios, A. (2014). Organizational culture and job satisfaction: A review. International Review of Management and Marketing, 4(2), 132-149.

[7] Arifin, H. M. (2015). The Influence of Competence, Motivation, and Organisational Culture to High School Teacher Job Satisfaction and Performance. International Education Studies, 8(1), 38-45.

[8] Ahsan Mansur,Titi Nurfitri, Muhammad Arifin Mukti, Tohir. (2019). The Role Of Job Satisfaction On The Relationship Between Self-Leadership And Organizational Citizenship Behaviour. Journal of Research in Management Vol. 2, No. 2, 2019, pp. 7 - 13

[9] Paillé, P., \& Raineri, N. (2015). Linking perceived corporate environmental policies and employees eco-initiatives: The influence of perceived organizational support and psychological contract breach. Journal of business Research, 68(11), 2404-2411

[10] Boiral, O., Talbot, D., \& Paillé, P. (2015). Leading by example: A model of organizational citizenship behavior for the environment. Business Strategy and the Environment, 24(6), 532550

[11] Ju, S. Y., Azlinna, A., \& Thurasamy, R. (2015). Environmental leadership and employees' organizational citizenship behavior towards the environment (OCBE): Psychological distance as a moderating variable'. In Advances in Global Business Research: Proceedings of the 12th Annual World Congress of the Academy for Global Business Advancement (AGBA) (pp. 1619).

[12] Han, Z., Wang, Q., \& Yan, X. (2019). How Responsible Leadership Motivates Employees to Engage in Organizational Citizenship Behavior for the Environment: A Double-Mediation Model. Sustainability, 11(3), 605.

[13] Ju, S. Y., Azlinna, A., \& Thurasamy, R. (2015). Environmental leadership and employees' organizational citizenship behavior towards the environment (OCBE): Psychological distance as a moderating variable'. In Advances in Global Business Research: Proceedings of the 12th Annual World Congress of the Academy for Global Business Advancement (AGBA) (pp. 1619).

[14] Pham, N. T., Phan, Q. P. T., Tučková, Z., Vo, N., \& Nguyen, L. H. (2018). Enhancing the organizational citizenship behavior for the environment: the roles of green training and organizational culture. Management \& Marketing. Challenges for the Knowledge Society, 13(4), 1174-1189.

[15] Busro, M. (2018). Teori-teori Manajemen Sumber Daya Manusia. Prenadamedia Group. Jakarta. 
[16] Sutrisno, E. (2017). Manajemen Sumber Daya Manusia. Prenadamedia Group. Jakarta.

[17] Stephen P. Robbins, A. Timothy A. Judge.2018.Essentials of Organizational Behavior, 14th Edition. Pearson

[18] Boiral, O., \& Paillé, P. (2012). Organizational citizenship behaviour for the environment: Measurement and validation. Journal of business ethics, 109(4), 431-445 